\title{
The Impact of Brand Image on Consumer Behavior: A Literature Review
}

\author{
Yi Zhang \\ Department of Marketing, Management School, Jinan University, Guangzhou, China \\ Email: rebeccazhang2013@163.com
}

Received 20 December 2014; accepted 8 January 2015; published 16 January 2015

Copyright @ 2015 by author and Scientific Research Publishing Inc.

This work is licensed under the Creative Commons Attribution International License (CC BY). http://creativecommons.org/licenses/by/4.0/

(c) (9) Open Access

\begin{abstract}
The concept "brand image" has drawn significant attention from academics and practitioners since it was put forward, because it played an important role in marketing activities. Although brand image was recognized as the driving force of brand asset and brand performance, few studies have elaborated on the relationship between brand image and brand equity. Based on the brand image theories, this study reviewed extant studies about the impact of brand image on consumer from perspective of customer equity. It also presented the shortcomings of current research and pointed out the trends for future study.
\end{abstract}

\section{Keywords}

Brand Image, Customer Equity, Consumer Behavior

\section{Introduction}

Brand image is the key driver of brand equity, which refers to consumer's general perception and feeling about a brand and has an influence on consumer behavior. For marketers, whatever their companies' marketing strategies are, the main purpose of their marketing activities is to influence consumers' perception and attitude toward a brand, establish the brand image in consumers' mind, and stimulate consumers' actual purchasing behavior of the brand, therefore increasing sales, maximizing the market share and developing brand equity.

Brand equity is the focus of both academics and practitioners; however, there is no paradigm among the brand equity studies by now. Most studies measure brand equity from perspective of consumer or from the company itself. On one hand, some researchers believe that consumers' subjective perception (e.g., attitude, assessment, satisfaction, etc.) of the brand is the key to brand equity. Although the consumption decision will be influenced by brand features and attributes, it is determined by consumers' perception about the brand image in a deeper sense. Despite the change of consumers' life style and the way of information processing, brand image remains 
the dominant impact factor of consumption decisions. On the other hand, some researchers believe that brand equity should be evaluated in terms of market share, market value and cash flow.

Also, extant studies take financial performance and non-financial performance as the manifestation of brand equity. Financial performance can be described as brand premium and market share; non-financial performance refers to the brand awareness, brand reputation, brand loyalty and brand association. Following the brand equity analysis in the perspective of consumer and perspective of non-financial performance, this study analyzes the relationship between brand image and brand equity by examining consumers' attitude and purchase intention.

\section{The Literature Review about Brand Image}

According to Park et al. (1986), the construction and maintenance of the brand image is prerequisite to the brand management [1]. Theoretically, all products and services could be demonstrated by functional, symbolic or experimental elements, through which brand image is established. Up to now, scholars haven't come to an agreement on the definition of brand image. Throughout prior literature, researchers define brand image mainly from four perspectives: blanket definitions, meanings and messages, personification, cognitive or psychological elements [2], as displayed in Table 1.

\section{Brand Image and Consumer Behavior}

Brand image has been studied extensively since the $20^{\text {th }}$ century due to its importance in building brand equity. In the increasingly competitive world marketplace, companies need to have a deeper insight into consumer behavior and educate consumers about the brand in order to develop effective marketing strategies. In the following paragraph, we will discuss the relationship between consumers' cognition of brand image and consumer behavior.

\subsection{Impact of Brand Image on Customer's Attitude toward the Brand}

Keller came up with the concept "customer-based brand equity (CBBE)" in 1993, which refers to the various reactions to the branding campaign from consumers who have knowledge of the brand in varying degrees. In other words, brand image and brand awareness are the basis and sources of brand equity. According to Keller (1993), positive brand image could be established by connecting the unique and strong brand association with

Table 1. Brand image concept in the brand literature.

\begin{tabular}{|c|c|c|}
\hline Perspective & Sources & Definition of brand image \\
\hline \multirow{3}{*}{ Blanket definitions } & Herzog (1963) [3] & Consumers'general perception and impression of a brand \\
\hline & Newman (1985) [4] & Consumers'perception of a product's total attributes \\
\hline & Dichter (1985) [5] & Consumers'general impression of the product or service \\
\hline \multirow{3}{*}{$\begin{array}{l}\text { Meanings and } \\
\text { messages }\end{array}$} & Noth (1988) [6] & The symbolic meaning embedded in the product or service \\
\hline & Sommers (1964) [7] & Consumers'perception and recognition of a product's symbolic attribute \\
\hline & Levy (1973) [8] & The symbolic meaning of purchasing the product or service \\
\hline \multirow{3}{*}{ Personification } & Martineau (1957) [9] & $\begin{array}{l}\text { Brand image reflects consumers'characteristics, and they purchase the brand to } \\
\text { express themself }\end{array}$ \\
\hline & Bettinger (1979) [10] & The personification of a product, which can be manifested as "adult" and "children" \\
\hline & Sirgy (1985) [11] & Image of the brand resembles human personality \\
\hline \multirow{4}{*}{$\begin{array}{l}\text { Cognitive or } \\
\text { psychological elements }\end{array}$} & Gardner \& Levy (1955) [12] & $\begin{array}{l}\text { Brand image is consisted of consumers'opinion, attitude and emotion toward a } \\
\text { brand, which reflects the cognitive or psychological elements of the brand }\end{array}$ \\
\hline & Levy (1978) [13] & $\begin{array}{l}\text { Consumers'overall impression about a brand or product, which includes recognition, } \\
\text { feeling and attitude toward it }\end{array}$ \\
\hline & Bullmore (1984) [14] & Consumers'general perception and opinion of a brand's total attributes \\
\hline & Kapferer (1994) [15] & Consumers'general perception about the brand feature's association \\
\hline
\end{tabular}


consumers' memories about the brand through marketing campaigns [16]. In this regard, the brand knowledge should be built and understood before the consumers could respond positively to the branding campaign. If consumers have knowledge of a brand, the company could spend less on brand extension while achieve higher sales [17].

Following Keller (1993), Lassar et al. (1995) held the opinion that brand equity came from the customers' confidence in a brand. The greater the confidence they place in the brand, the more likely they are willing to pay a high price for it [18]. Specifically, this confidence stems from five important considerations: first, the brand performs its functions as designed; second, the social image is associated with purchasing or owning the brand; third, consumers' recognition and sentimental attachment with brand; fourth, the balance between the brand's value and its functionalities; fifth, consumers trust in the brand. Netemeyer et al. (2004) also approved the dominant impact of brand equity on customer response toward the branding campaign [19].

With the proliferation of brands in the market, consumers make their purchase decisions largely depending on the brand image rather than the product itself. Moreover, when the brand image is consistent with the consumers' self-concept, the consumers would give a preference to it [9]. According to the self-concept theory, one's selfconcept is a collection of perception about himself that includes elements such as capabilities, characteristics, shortcomings, appearance and personality [20]. For marketers, examining the consistency between the brand image and consumers' self-concept is very important, because consumers might display various self-concepts in different social context. But whatever the context is, consumers would think better of the brand as long as the brand image is in line with the their self-concept [21].

\subsection{Impact of Brand Image on Consumer's Behavioral Intention}

Looking through extant researches, the most widely used predictors of consumer's behavioral intention are customer satisfaction and customer loyalty.

Customer satisfaction refers to customers' general evaluation of the overall shopping experience of some specific product or service [22]. According to Oliver (1980), customers' performance-specific expectation and expectation disconfirmation are the key indicators of customer satisfaction [23]. Specifically, when the product performance exceeds expectation, customer satisfaction increases; when expectation exceeds the product performance, customer satisfaction decreases. Since product performance is an important component of brand image, companies could infer the potential influence of brand image on customer satisfaction by identifying the perceptual difference toward a brand between the existing customers and non-users of the brand [24].

Brand image has a significant impact on customer satisfaction especially across the E-banking, landline, mobile phone, bank and supermarket industries [25]. Chang et al. (2005) identified store infrastructure, convenience, store service and sales activities as the four components of store image, and they all impact customer satisfaction directly [26]. Chitty et al. (2007) also empirically proved the dominant role of brand image in predicting customer satisfaction in the hospitality industry [27]. Moreover, the congruence between the brand image and customers' self-image would enhance customer satisfaction and customers' preference for the brand [28].

Customer loyalty could be recognized as the extension of customer satisfaction. Earlier studies define customer loyalty as repeated purchasing behaviors in a narrow sense. Generally, customer loyalty stems from customers' approval of a brand, which leads to their continuously purchasing behavior of the brand and thus generates profits for the company [29]. In the brand image literature, brand image is perceived as an important driving force of customer loyalty. For the supermarket industry, favorable store image is very helpful to foster customer loyalty [30] [31]. Even in the virtual context, the impact of brand image on customer loyalty remains significant [32], and Merrilees \& Fry (2002) verified their relationship through surveys at e-commerce companies [33].

\section{Suggestions for Future Study}

\subsection{Enrich the Connotation of Brand Image}

In the last decade, emotional branding has become a very influential manner of brand management [34] [35]. As suggested by Roberts (2004), brand emotion is the cultural implication embodied in a brand, and emotional branding is a highly effective way to cause customer reaction, sentiments and moods, ultimately forming connection and loyalty with the brand [36]. Even the traditional brand management pattern based on customer per- 
ception now has incorporated emotional branding into it. In the unprecedentedly competitive marketplace, brand emotion is the bond between the brand and the customer, and the key to expanding the market. Future studies could explore the relationship between brand image and consumer behavior from a brand new perspective-brand emotion.

\subsection{Brand Image, Customer Satisfaction and Customer Loyalty}

The relationship between brand image and customer satisfaction has been studied extensively. However, a majority of these researches were conducted in service industry, such as hotel, supermarket and bank, etc. Whether the results generated from the service industry can be applicable to other contexts (e.g., manufacturing industry, finance industry, real estate industry, etc.) remains to be examined.

Moreover, although the positive impact of brand image on customer satisfaction and customer loyalty has been testified, there still exist minor disagreements between different researches. Specifically, some studies prove that brand image not only influences customer loyalty directly, but also impacts on it through other mediating factors. However, some research results demonstrate that brand image exerts no direct influence on customer loyalty, but it can impact on customer loyalty via customer satisfaction. Future studies should further discuss the interrelationships among brand image, customer satisfaction and customer loyalty, and identify a more comprehensive indicator for consumer behavior.

\section{References}

[1] Park, C.W., Jaworski, B.J. and Maclnnis, D.J. (1986) Strategic Brand Concept-Image Management. Journal of Marketing, 50, 135-145. http://dx.doi.org/10.2307/1251291

[2] Dobni, D. and Zinkhan, G.M. (1990) In Search of Brand Image: A Foundation Analysis. Advances in Consumer Research, 17, 110-119.

[3] Herzog, H. (1963) Behavioral Science Concepts for Analyzing the Consumer. In: Bliss, P., Ed., Marketing and the Behavioral Sciences, Allyn and Bacon, Inc., Boston, 76-86.

[4] Newman, S.L. (1985) Facies Interpretations and Lateral Relationships of the Blackhawk Formation and Mancos Shale, East-Central Utah. Rocky Mountain Section SEPM, 10, 60-69.

[5] Dichter, E. (1985) What's in an Image. Journal of Consumer Marketing, 2, 75-81. http://dx.doi.org/10.1108/eb038824

[6] Noth, W. (1988) The Language of Commodities Groundwork for a Semiotics of Consumer Goods. International Journal of Research in Marketing, 4, 173-186. http://dx.doi.org/10.1016/S0167-8116(88)80003-X

[7] Sommers, M.S. (1964) Product Symbolism and the Perception of Social Strata. Proceedings of the American Marketing Association, Chicago.

[8] Levy, S.J. (1973) Imagery and Symbolism. In:Steward, H.B., Ed., Brands, Consumers, Symbols and Research, Sidney J Levy on Marketing, Dartnell, Chicago, 233.

[9] Martineau, P. (1957) Motivation in Advertising. Journal of Marketing Research, February, 35-40.

[10] Bettinger, C.O., Dawson Jr., L.E. and Wales, H.G. (1979) The Impact of Free-Sample Advertising. Journal of Advertising Research, 19, 35-39.

[11] Sirgy, M.J. (1985) Using Self-Congruity and Ideal Congruity to Predict Purchase Motivation. Journal of Business Research, 13, 195-206. http://dx.doi.org/10.1016/0148-2963(85)90026-8

[12] Gardner, B.B. and Levy, S.J. (1955) The Product and the Brand. Harvard Business Review, March-April, 33-39.

[13] Levy, S.J. (1978) Marketplace Behavior-Its Meaning for Management. Amacom, New York.

[14] Bullmore, J. (1984) The Brand and Its Image Revisited. International Journal of Advertising, 3, 235-238.

[15] Kapferer, J.-N. (1994) Strategic Brand Management: New Approaches to Creating and Evaluating Brand Equity. Free Press, New York.

[16] Keller, K.L. (2003) Brand Synthesis: The Multidimensionality of Consumer Knowledge. Journal of Consumer Research, 29, 595-600. http://dx.doi.org/10.1086/346254

[17] Smith, D.C. and Whan Park, C. (1992) The Effects of Brand Extensions on Market Share and Advertising Efficiency. Journal of Marketing Research, 29, 296-313. http://dx.doi.org/10.2307/3172741

[18] Lassar, W., Mittal, B. and Sharma, A. (1995) Measuring Customer-Based Brand Equity. Journal of Consumer Marketing, 12, 11-19. http://dx.doi.org/10.1108/07363769510095270

[19] Netemeyer, R.G., Krishnan, B., Pullig, C., Wang, G.P., Yagci, M., Dean, D., Ricks, J. and Wirth, F. (2004) Developing 
and Validating Measures of Facets of Customer-Based Brand Equity. Journal of Business Research, 57, 209-224. http://dx.doi.org/10.1016/S0148-2963(01)00303-4

[20] Rosenberg, M. (1979) Conceiving the Self. Basic Books, New York.

[21] Graeff, T.R. (1997) Consumption Situations and the Effects of Brand Image on Consumers' Brand Evaluations. Psychology \& Marketing, 14, 49-70. http://dx.doi.org/10.1002/(SICI)1520-6793(199701)14:1<49::AID-MAR4>3.0.CO;2-O

[22] Fornell, C. (1992) A National Customer Satisfaction Barometer: The Swedish Experience. Journal of Marketing, 56, 621. http://dx.doi.org/10.2307/1252129

[23] Oliver, R.L. (1980) A Cognitive Model of the Antecedents and Consequences of Satisfaction Decisions. Journal of Marketing, 17, 460-469. http://dx.doi.org/10.2307/3150499

[24] Bird, M., Channon, C. and Ehrenberg, A.S.C. (1970) Brand Image and Brand Usage. Journal of Marketing Research, 7, 307-314. http://dx.doi.org/10.2307/3150287

[25] Gronholdt, L., Martensen, A. and Kristensen, K. (2000) The Relationship between Customer Satisfaction and Loyalty: Cross-Industry Differences. Total Quality Management, 11, 509-514. http://dx.doi.org/10.1080/09544120050007823

[26] Chang, C.H. and Tu, C.Y. (2005) Exploring Store Image, Customer Satisfaction and Customer Loyalty Relationship: Evidence from Taiwanese Hypermarket Industry. Journal of American Academy of Business, 7, 197-202.

[27] Chitty, B., Ward, S. and Chua, C. (2007) An Application of the ECSI Model as a Predictor of Satisfaction and Loyalty for Backpacker Hostels. Marketing Intelligence \& Planning, 25, 563-580. http://dx.doi.org/10.1108/02634500710819941

[28] Jamal, A. and Goode, M.M. (2001) Consumers and Brands: A Study of the Impact of Self-Image Congruence on Brand Preference and Satisfaction. Marketing Intelligence \& Planning, 19, 482-492. http://dx.doi.org/10.1108/02634500110408286

[29] Keller, K.L. (1993) Conceptualizing, Measuring, and Managing Customer-Based Brand Equity. Journal of Marketing, 57, 1-22. http://dx.doi.org/10.2307/1252054

[30] Kunkel, J.H. and Berry, L.L. (1968) A Behavioral Conception of Retail Image. Journal of Marketing, 32, 21-27. http://dx.doi.org/10.2307/1249333

[31] Koo, D.-M. (2003) Interrelationships among Store Images, Store Satisfaction, and Store Loyalty among Korea Discount Retail Patrons. Asia Pacific Journal of Marketing and Logistics, 15, $42-71$. http://dx.doi.org/10.1108/13555850310765033

[32] Da Silva, R.V. and Alwi, S.F.S. (2006) Cognitive, Affective Attributes and Conative, Behavioural Responses in Retail Corporate Branding. Journal of Product \& Brand Management, 15, 293-305. http://dx.doi.org/10.1108/10610420610685703

[33] Merrilees, B. and Fry, M.-L. (2002) Corporate Branding: A Framework for E-Retailers. Corporate Reputation Review, 5, 213-225. http://dx.doi.org/10.1057/palgrave.crr.1540175

[34] Gobe, M. (2001) Emotional Branding: The New Paradigm for Connecting Brands to People. Allworth Press, New York.

[35] Zaltman, G. (2003) How Customers Think: Essential Insights into the Mind of the Market. Harvard University Press, Cambridge.

[36] Roberts, K. (2004) Lovemarks: The Future beyond Brands. Powerhouse Books, New York. 
Scientific Research Publishing (SCIRP) is one of the largest Open Access journal publishers. It is currently publishing more than 200 open access, online, peer-reviewed journals covering a wide range of academic disciplines. SCIRP serves the worldwide academic communities and contributes to the progress and application of science with its publication.

Other selected journals from SCIRP are listed as below. Submit your manuscript to us via either submit@scirp.org or Online Submission Portal.
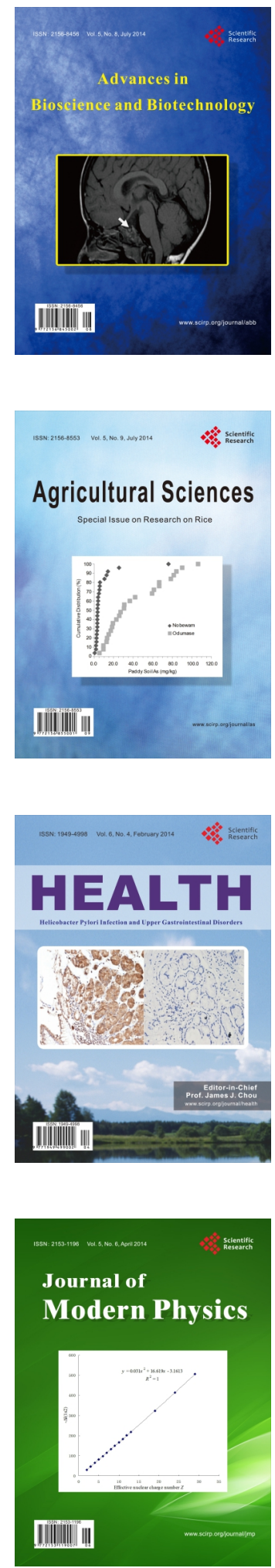
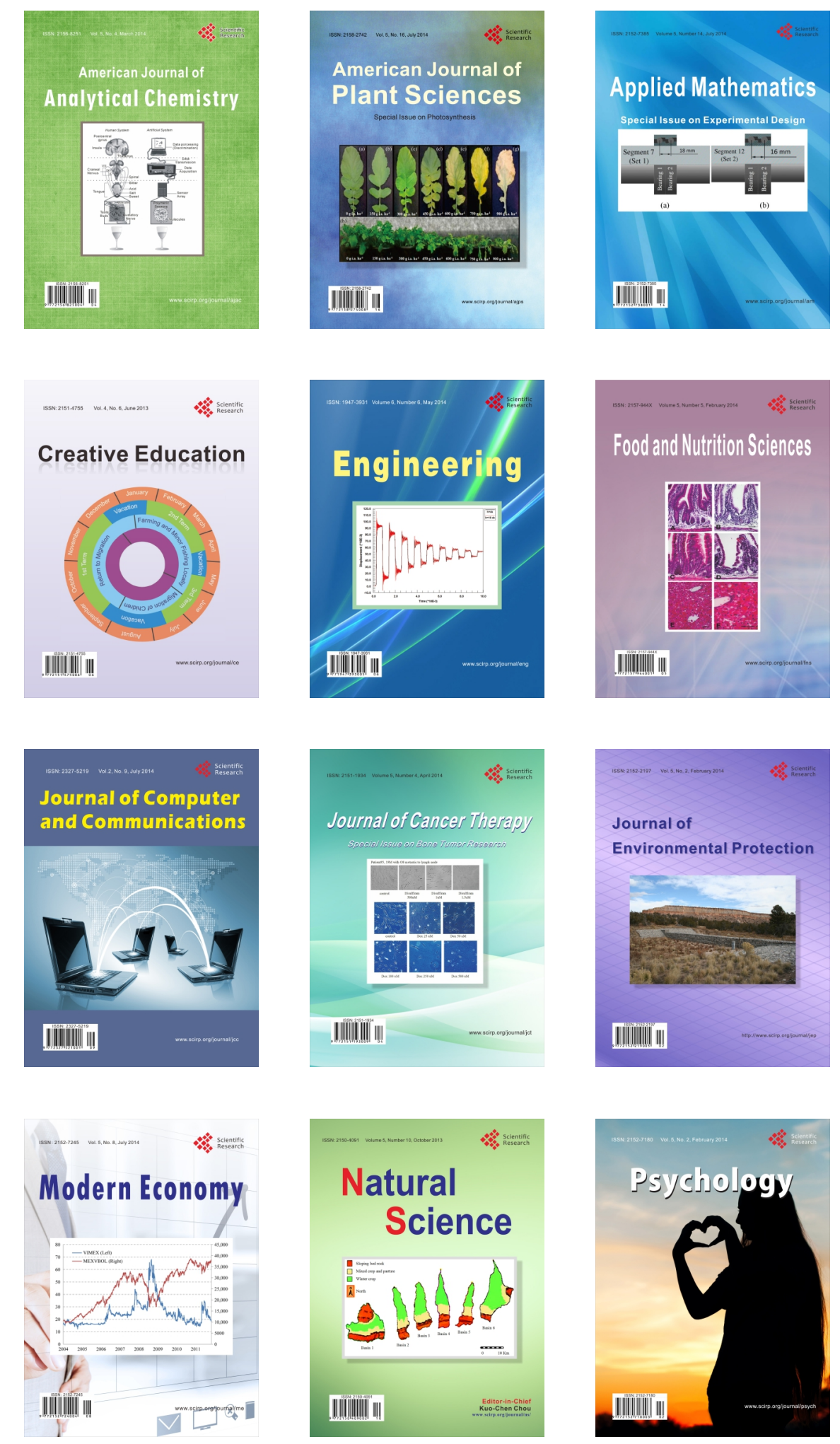